\title{
Value capture for transportation finance
}

\author{
Zhirong Zhao*, Michael Iacono, Adeel Lari, David Levinson ${ }^{\text {a }}$ \\ ${ }^{a}$ All the authors work at University of Minnesota
}

\begin{abstract}
Value capture seeks to generate revenue by extracting a portion of the gains in the value of land that result from improvements to transportation networks. In this paper we identify value capture strategies, including land value taxes, tax increment financing, special assessments, transportation utility fees, development impact fees, negotiated exactions, joint development, and air rights. We evaluate each of the policies according to four criteria: efficiency, equity, sustainability, and feasibility. The value capture concept is placed within a more general framework of transportation finance that emphasizes the relationship between different types of charges and groups of beneficiaries from transportation investments.
\end{abstract}

(C) 2012 Published by Elsevier Ltd. Selection and/or peer review under responsibility of the Programme Committee of the Transport Research Arena 2012 Open access under CC BY-NC-ND license.

Keywords: Transportation economics; Land value; Finance and taxation; Urban economics

\section{Introduction}

In the majority of jurisdictions in the United States with responsibility for providing transportation infrastructure and services, the structure of systems of transportation finance is changing in ways that may necessitate major changes in the next couple of decades. Taxes on motor fuels, long a mainstay of the current system of finance at the federal and state levels, are weakening as a base of support in light of reduced fuel consumption and the longer-term transition to vehicles that rely less (or perhaps not at all) on gasoline as a fuel for propulsion. Likewise, more direct forms of user charging for road use, such as congestion pricing, have proven politically difficult (Harsman \& Quigley, 2010). Local units of government, which tend to rely more heavily on general purpose taxes such as property taxes, often

${ }^{*}$ Corresponding Author;

E-mail address: zrzhao@umn.edu 
encounter strong resistance to proposals to generate additional revenue from these sources. These and other factors are forcing a reassessment of the ways in which transportation is financed and delivered.

One alternative mechanism for financing transportation is to tax the value of land generated by transportation improvements. The term "value capture" can be applied to a range of policies that adopt this approach. In this paper, we identify eight different policies that may be classified as value capture policies. These include:

- Land Value Taxes

- Tax Increment Financing

- Special Assessments

- Transportation Utility Fees

- Development Impact Fees

- Negotiated Exactions

- Joint Development

- Air Rights

Before formally introducing the set of value capture policies, we provide a rationale for the value capture concept by placing it within a more general framework of transportation finance, which defines different funding mechanisms on the basis of their relationship to specific groups of beneficiaries. We then introduce the policies by describing them in terms of a set of eight common features: which party contributes toward infrastructure provision (developers or property owners); what type of coordination each policy involves; timing; spatial extent of the policy; the basis of the infrastructure charges (whether they fall on new or old development); the types of costs to which they may be applied; ownership of the transportation infrastructure; and the level of government responsible for administering the policy. The policies are then evaluated according to a set of criteria derived from principles of public finance. These include economic efficiency, social equity, sustainability (in terms of the ability to generate adequate revenue streams continuously), and political and administrative feasibility.

\section{The Study of Value Capture}

The concept of land value capture has a storied history dating to the work of economist Henry George (George, 1975), which first appeared in the late 19th century. Interest in the concept has been revived in recent years, sometimes under different names. For example, Foldvary (2005) has referred to the concept using the term "geo-rent," which is designed to avoid the confusion that occasionally surrounds other related terms like "land rent." The idea of taxing land value has always held some theoretical appeal, not least because of its potential as a less distortionary form of taxation. The fixity of supply and immobility of land make it an attractive tax base, particularly for more local units of government. Some authors have suggested that taxes on the value of urban land may be an ideal way to pay for a variety of local services, replacing other general sources of revenue such as property taxes (Vickrey, 2001). The price of land tends to capitalize the value of many types of public goods, including the accessibility provided by transportation networks. In locations of high accessibility, this value can be quite substantial, and thus play a more important role in transportation finance.

The relationship between transportation networks and land value has been established in a large body of empirical research that includes several attempts to synthesize previous work (Huang, 1996; Ryan, 1999; Giuliano, 2004; Smith \& Gihring, 2006; Debrezion, Pels, \& Rietveld, 2007). Despite this accumulated evidence, there has been surprisingly little interest in applying the principles of value capture to the field of transportation. Much of what has been written on the subject has tended toward the development of conceptual frameworks (Hayashi, 1989; Stopher, 1993) or to stylized examples and 
simulations of hypothetical applications (Allen, 1987; Dalvi \& Patankar, 1999; Batt, 2001; Du \& Mulley, 2007; Vadali, Aldrete, \& Bujanda, 2009). This paper aims to extend the knowledge base on the topic by providing new frameworks for thinking about value capture and for evaluating policy instruments that embody its principles.

\section{Value Capture in a General Framework of Transportation Finance}

To understand value capture better, we propose a general framework of transportation finance. Following the benefit principle that the cost of transportation for a contributor should be proportional to the benefits received, different instruments of transportation finance may be designed to match different categories of transportation benefits and the different ways in which these benefits are measured. As Table 1 shows, the beneficiaries can fall under three broad categories: the unrestricted general public; restricted non-user beneficiaries; and direct users of transportation facilities.

In the broadest sense, transportation improvements create benefits for the general public within the whole jurisdiction, because the enhanced infrastructure may lead to economic or social returns signified by the growth of the general tax base. Accordingly, transportation finance may be allocated from a government general fund that comes from all revenue sources. This is the case for many local governments in the United States and many other countries. Identifying this general benefit is, however, the most difficult, as it is hard to disentangle the general public benefit from the benefits received by individual members of the public.

Most directly, transportation benefits are enjoyed by users of transportation facilities, such as vehicle operators or transit passengers. This provides the rationale of dedicated special revenues for transportation. For vehicle operators, the corresponding financial instruments would be gas taxes, distance-based (mileage) charges, vehicle sales taxes or vehicle property taxes, wheelage charges, or tolls, depending on how driving benefits are measured. Some options above, such as gas taxes or vehicle sales taxes, have been widely used by the U.S. federal government and the states. Other options, such as mileage-based charges or wheelage based charges, are also increasingly considered. For transit passengers, the corresponding financial instruments would be fares or permits.

Between the general public and direct users, we can also define a restricted group of beneficiaries who are not direct users of transportation facilities but who enjoy benefits because of their enhanced location advantages. As these property owners or developers benefit from transportation value creation, they are the targeted contributors of value capture. Different ways to measure the value gains give rise to a range of different value capture policies.

Some value capture policies would impact property owners:

- Land-Value Taxes (or split-rate property taxes) may be levied to capture the general increase in the price of land due to enhanced accessibility;

- Tax Increment Financing may be used because improved transportation facilities will contribute to the growth of property tax within a TIF district;

- Special assessments may be levied if the direct special benefits for some properties due to transportation improvements exceed those that accrue to the general public, and can be clearly identified and measured within a special assessment district; and

- Transportation Utility Fees may be collected if the utility of transportation improvements is measured with the proxy of property types or sizes. 
Table 1: Value capture in the general framework of transportation finance

\begin{tabular}{|c|c|c|c|c|c|c|}
\hline \multirow{2}{*}{$\begin{array}{l}\text { Funding } \\
\text { Mechanism }\end{array}$} & \multirow[t]{2}{*}{ Beneficiaries } & & \multirow{2}{*}{$\begin{array}{l}\text { Measurement of } \\
\text { Benefit }\end{array}$} & \multirow{2}{*}{$\begin{array}{l}\text { Finance } \\
\text { Instrument }\end{array}$} & \multicolumn{2}{|c|}{ Cost Type } \\
\hline & & & & & Upfront & Ongoing \\
\hline $\begin{array}{l}\text { General } \\
\text { Revenue }\end{array}$ & General public & & General tax base growth & $\begin{array}{l}\text { General fund alloca- } \\
\text { tion; property tax; } \\
\text { transportation sales } \\
\operatorname{tax}\end{array}$ & - & $\bullet$ \\
\hline \multirow[t]{7}{*}{$\begin{array}{l}\text { Value } \\
\text { Capture }\end{array}$} & $\begin{array}{l}\text { Restricted non- } \\
\text { user beneficiaries }\end{array}$ & Landowners & $\begin{array}{l}\text { Land value growth } \\
\text { Property tax growth }\end{array}$ & $\begin{array}{l}\text { Land Value Taxes } \\
\text { Tax Increment } \\
\text { Financing }\end{array}$ & - & $\bullet$ \\
\hline & & & Assessed special benefits & Special Assessment & $\bullet$ & \\
\hline & & & Transportation utility & $\begin{array}{l}\text { Transportation Utility } \\
\text { Fees }\end{array}$ & & - \\
\hline & & Developers & $\begin{array}{l}\text { Off-site development } \\
\text { opportunities }\end{array}$ & $\begin{array}{l}\text { Development Impact } \\
\text { Fees }\end{array}$ & - & \\
\hline & & & Off-site access benefits & Negotiated Exactions & $\bullet$ & - \\
\hline & & & Development privileges & Joint Development & - & - \\
\hline & & & $\begin{array}{l}\text { On-site development } \\
\text { opportunities }\end{array}$ & Air Rights & $\bullet$ & $\bullet$ \\
\hline \multirow[t]{6}{*}{ User Fees } & $\begin{array}{l}\text { Users of } \\
\text { transportation } \\
\text { facilities }\end{array}$ & $\begin{array}{l}\text { Vehicle } \\
\text { operators }\end{array}$ & $\begin{array}{l}\text { Gas consumption } \\
\text { Mileage }\end{array}$ & $\begin{array}{l}\text { Gas taxes } \\
\text { Mileage-based } \\
\text { charges }\end{array}$ & - & - \\
\hline & & & Vehicle units/types & $\begin{array}{l}\text { Vehicle sales tax; } \\
\text { license tab fee; } \\
\text { wheelage charges }\end{array}$ & $\bullet$ & $\bullet$ \\
\hline & & & General access rights & Tolling & & - \\
\hline & & & $\begin{array}{l}\text { Demand-controlled } \\
\text { access rights }\end{array}$ & Congestion pricing & & $\bullet$ \\
\hline & & & $\begin{array}{l}\text { Rights to incur environ- } \\
\text { mental impacts }\end{array}$ & $\begin{array}{l}\text { Transportation envi- } \\
\text { ronmental taxesifees }\end{array}$ & & $\bullet$ \\
\hline & & Passengers & Ridership & Fare or permits & & - \\
\hline
\end{tabular}

Others would impact developers:

- Development Impact Fees or impact taxes pay for enhanced off-site infrastructure;

- Negotiated Exactions require developers to forfeit part of their land in exchange for off-site transportation benefits;

- Joint Development involves collaboration with the public sector simultaneously to improve transportation while developing land; or

- Air Rights allow development on top of existing or new transportation facilities in exchange for a financial contribution or future additional property and income taxes.

Note that transportation improvements may create value in many different ways simultaneously, and so multiple value capture policies can be combined. However, the total level of value capture cannot exceed the total benefits created by transportation, otherwise the financial instruments would negate the economic rationale of development. 
The last column of Table 1 shows the suitable cost types that can be financed by each transportation finance instrument. Ideally, cost types should be matched with the timing of transportation benefits. Typically, direct users of transportation facilities receive the bulk of their benefits through the use of facilities, and thus the corresponding special revenues are most suitable for ongoing operation and management $(\mathrm{O} \& \mathrm{M})$ costs. The growth of the general tax base occurs through the life cycle of a transportation facility, and thus the corresponding general fund revenues are suitable for both upfront capital cost and O\&M cost. For value capture beneficiaries (property owners and developers), their value gains due to enhanced locational advantages are mostly realized upon the completion of transportation facilities and, as such, the corresponding value capture policies may be used more often for capital cost. For example, negotiated exactions are typically used for the capital cost only as a way to reduce the fixed cost for the right-of-way. Transportation utility fees (TUF), however, are more closely related to the daily usage of facilities and thus TUF may be more suitable for O\&M cost.

It should be noted that any financial instrument can be used for any cost occurring at any time with appropriate planning and use of debt and annuity instruments. An agency could use ongoing revenue to pay back debt acquired to pay for capital costs, or could charge a one-time fee to fund an annuity to pay for ongoing costs. This is somewhat more complicated than the pay-as-you-go mechanism many jurisdictions prefer to reduce transaction and interest costs, and also disassociates benefits from costs.

\section{Value Capture Policies and Their Features}

With the concept of value capture firmly situated within a broader framework of transportation finance, we may turn our attention to the individual value capture policies themselves. We have identified eight different policies that can be classified as value capture policies. Table 2 identifies these policies and presents the features of each policy in eight dimensions. The policies listed in Table 2 are land value taxes, tax increment financing, special assessments, transportation utility fees, development impact fees, negotiated exactions, joint development, and air rights. The dimensions along which these policies may be classified are discussed below.

\subsection{Contributor}

The first dimension identifies which party is being asked to contribute resources toward transportation improvements, and is split between property owners and developers. Joint development, air rights, and development impact fees and negotiated exactions tend to shift the required contributions toward developers, as they apply mainly to new development. Land value taxes, transportation utility fees, and special assessments can be applied to both new development and existing property owners.

\subsection{Coordination}

The second dimension along which value capture policies can be characterized is the type of coordination required to administer the policy. As Table 2 indicates, many of the policies listed require oversight from a specific taxing authority. In many cases, this could be accomplished through an existing city or county assessor's office. Negotiated exactions and air rights generally involve the level of charges or in-kind provision of infrastructure being determined through a less formal negotiation process. Joint development policies, by their nature, involve the formation of a partnership between the public and private parties involved, through which the costs of infrastructure development and ownership arrangements can be determined. 
Table 2. Features of value capture policies

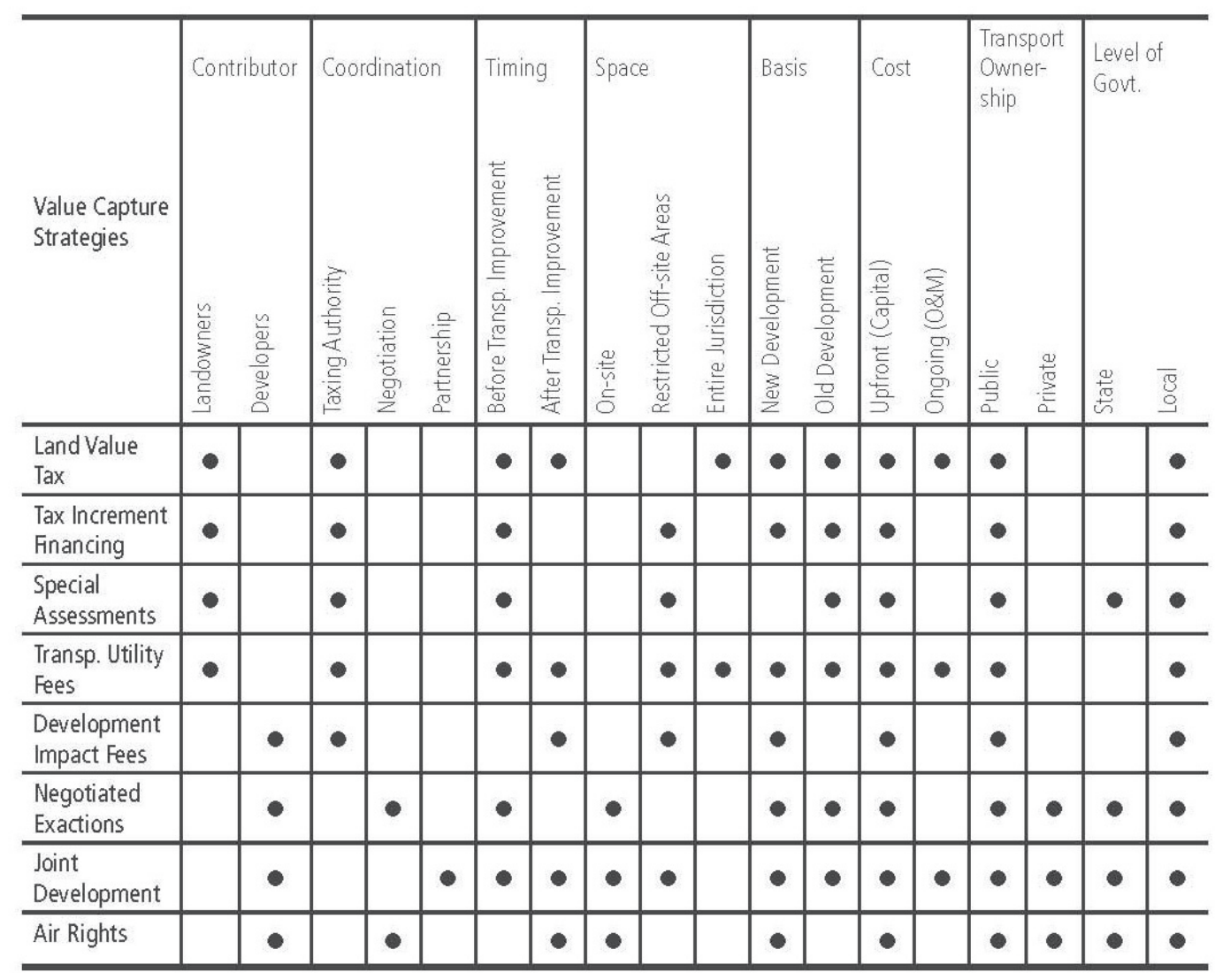

\subsection{Timing}

A third way to classify the different policies is to group them according to whether the policy is implemented before or after the associated transportation improvement takes place. Some policies are implemented prior to the transportation improvement. Tax increment finance and special assessment policies typically require delineating a special district on or near the site of the transportation improvement, a characteristic that leads them to be established in advance of the improvement. Likewise, exactions are typically negotiated during the planning process for a new development, and so precede the transportation improvement that confers additional value on that development. Air rights arrangements are typically implemented following a transportation improvement, since it is the additional access provided by the improvement that generates additional land value and attracts development. Several types of policies are implemented prior to a transportation improvement and continue for long periods of time following the improvement. Some arrangements, like land value taxes, transportation utility fees, air rights, or joint development, may continue in perpetuity as a source of ongoing financing for operations and maintenance.

A similar way to view the different policies in terms of timing is to classify them according to the stage in the development process at which the tax or fee occurs. Figure 1 displays this classification by 
dividing the development cycle into five stages: undeveloped, land subdivision, building permitting, under construction, and occupancy. As the figure indicates, three of the policies (land value tax, special assessment, and tax increment financing) can be applied at any stage during the development cycle. Development impact fees and negotiated exactions are typically assessed during the subdivision and permitting stages of development. Joint development revenues can be collected at any stage between land development and occupancy. Transportation utility fees and air rights, since they require development to be complete before charges can be levied, take place only at the occupancy stage.
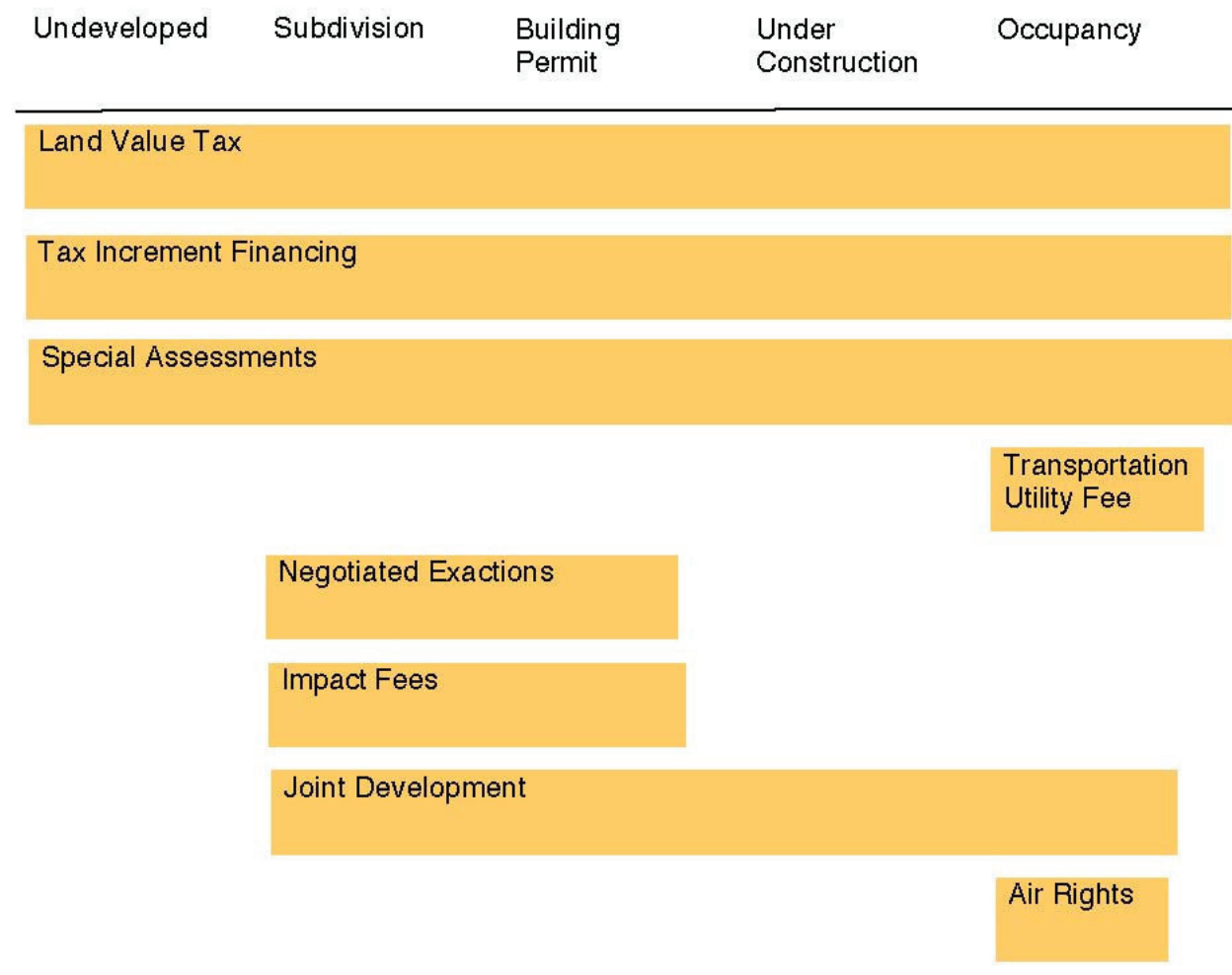

Fig. 1. Value capture policies classified by timing of tax imposition relative to stage in development cycle

\subsection{Space}

A fourth type of classification relates to the spatial reach of the affected area in which the value capture policy is implemented. Some are typically restricted to limited areas on the site of the transportation improvement, such as air rights and negotiated exactions. Land value taxes and transportation utility fees can be scaled up to the level of an entire jurisdiction, such as a city or county, to capture more generally the value of access provided by transportation networks. Tax increment finance and special assessment districts tend to be restricted to specific, restricted off-site areas near a transportation improvement, where value creation is believed to occur. Development impact fees are not always restricted to locations near a specific improvement, but can be limited in their spatial scope to the boundaries of political jurisdictions for administrative purposes. Joint development arrangements may be limited to the site of an improvement, as in the case of development on top of a public transit station, or extended to a restricted off-site area, as with the designation of special assessment districts.

A useful way to visualize the spatial relationship between the type of transportation improvement that takes place and the type of policy that might be adopted to capture its value is provided in Figure 2. 
Figure 2 distinguishes between link and nodal types of transportation improvements. As the figure indicates, air rights might be used in cases where development takes place directly on top of a link (e.g., decking a freeway link). Air rights might also be used for development that takes place directly on top of a nodal facility (such as a transit station), or in joint development arrangements. Development that takes place on a site adjacent to an improved link or node might be ideal for the application of negotiated exactions to recover the cost of the improvement. In cases where the influence of the facility on property values extends beyond the site of the improvement to nearby properties, an impact area (denoted in Figure 2 as the area shaded yellow) may be defined and used to collect revenues from property owners in the form of development impact fees, special assessments, or tax increment finance. Finally, some types of value capture policies apply at the scale of an entire jurisdiction. These include land value taxes and transportation utility fees.

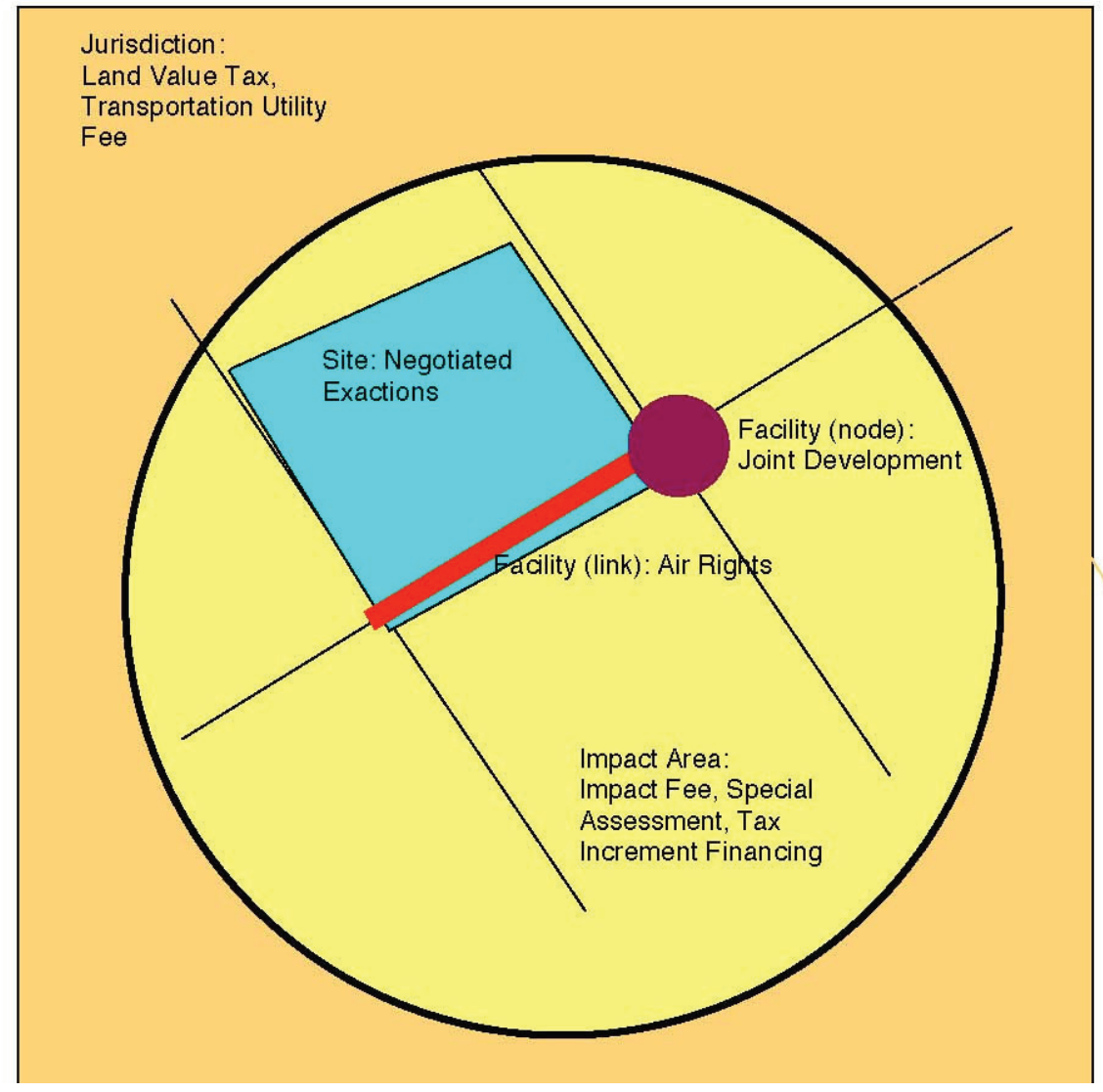

Fig. 2. Value capture policies classified by spatial effects

\subsection{Basis (new or old development)}

Value capture policies may also be distinguished in terms of whether they are applied strictly to new development or are extended to old development as well. Some policies, such as development impact fees, are designed to apply primarily to new development. Many of the policies listed can be designed so as to apply to both new and older development. Special assessment districts are exceptional in that they are applied mostly to older development. 


\subsection{Cost}

Another useful distinction for classifying value capture policies is to suggest whether the charges are used primarily to finance the initial capital cost of a transportation improvement, its recurring operational and maintenance costs, or both. Table 2 suggests that several of the policies considered here are designed to recover the initial capital costs of a transportation improvement. At least three of the policies (land value taxes, transportation utility fees, and joint development) have been or could potentially be applied both to capital costs and to ongoing operations and maintenance.

\subsection{Ownership}

A seventh dimension along which value capture policies can be distinguished relates to whether the road or other transportation facility that generates the gain in property value is owned publicly or privately. All eight of the value capture policies presented here can be applied in the case of public ownership, while a subset of them, including air rights, negotiated exactions, and joint development, lend themselves to situations where the improved transportation facility is privately owned.

\subsubsection{Risk}

An issue closely related to the ownership of transportation infrastructure and to issues of who is responsible for contributing to the provision of infrastructure is the issue of risk. Nearly all of the value capture policies just described involve the capture of value created by a transportation improvement through charges on affected landowners. However, all of these mechanisms involve some degree of financial risk in the sense that they rely on a large enough increment in property value being created to provide adequate revenue. It is worthwhile to consider who bears the bulk of the risk under each type of policy.

Policies that rely on up-front payments from developers for the provision of new infrastructure generally tend to transfer risk to developers. This might include policies related to development impact fees, negotiated exactions, and certain types of special assessment districts. The charges are borne as costs by developers, who must then rely on sufficient demand for new development to recover the associated costs. If population growth, economic growth, or other factors that affect the demand for housing or commercial development fall short of expectations, the developer will be unable to recover the costs of infrastructure provision and will likely incur a financial loss.

In contrast, policies that rely on future appreciation in property values to finance the costs of a transportation improvement tend to transfer risk to the public sector. Policies such as tax increment finance, land value taxes, and the creation of special assessment districts to finance specific transportation projects (e.g., streetcars, subway lines, etc.) are characterized by exposure to this type of risk. If the value created by a transportation improvement falls short of expectations, revenues from these types of mechanisms may be insufficient and require tax increases from other sources (e.g., general property taxes) to cover the shortfall. To the extent that they are used to finance capital costs of transportation improvements, air rights and joint development arrangements may also expose the public sector to these types of risks. If a government entity is unable to lease space or find reliable tenants in an air rights development or joint development, the resulting shortfall would have to be made up through other types of tax increases or user charges. This type of risk exposure needs to be accounted for during the planning stages for implementation of a value capture policy.

\subsection{Level of government}

An eighth, and related, dimension identifies which level of government (state or local) would most likely be responsible for implementing the policy. The term "local," as used here, may encompass both 
county and municipal levels of government. All of the policies listed here may be implemented at the local level, while a smaller subset of them may also be implemented by state-level organizations.

\section{Evaluation}

Classification of the value capture policies along the lines of the dimensions suggested in Table 2 gives a useful overview of their similarities and differences, in addition to hinting at where, when, and how they might be applied. Now we will take a look at each of the eight policies in greater depth. A brief overview and description of each of the policies will be provided, including some information on where each of the policies has been applied, both in the United States and abroad, when applicable. Each of the policies will then be evaluated according to a set of criteria that describes its desirability as a transportation revenue source.

Table 3. Criteria for evaluating value capture strategies

\begin{tabular}{|c|c|c|}
\hline Criterion & & Sample Questions \\
\hline \multirow[t]{3}{*}{ Efficiency } & & Is the cost to contributors related to the benefit they receive? \\
\hline & & $\begin{array}{l}\text { Will it provide price signals/incentives for travelers' behavior, priority of } \\
\text { investment, or governmental decisions? }\end{array}$ \\
\hline & & To what extent may it hinder economic development? \\
\hline \multirow[t]{14}{*}{ Equity } & Benefit equity & Is it fair to the contributors in terms of benefits they receive? \\
\hline & & Are there issues of equity by geographic areas? \\
\hline & & Are there concerns of intergenerational equity? \\
\hline & Capacity-to-pay & How closely does it relate to personal capacity-to-pay? \\
\hline & equity & Is it regressive or progressive for different income groups? \\
\hline & Adequacy & Is the revenue base broad or narrow? Is the (implicit) tax rate high or low? \\
\hline & & How much revenue can it raise? \\
\hline & & Would it be enough to replace traditional source of revenue? \\
\hline & Potential of growth & To what extent can the revenue catch up with income growth? \\
\hline & & To what extent can the revenue catch up with inflation? \\
\hline & & To what extent can the revenue catch up with need increases? \\
\hline & Stability & How volatile is the revenue? \\
\hline & & Is it cyclical or counter-cyclical? \\
\hline & Predictability & Is the revenue easily predictable? \\
\hline \multirow[t]{6}{*}{ Feasibility } & Political feasibility & Is the tax or fee visible to taxpayers or the public? \\
\hline & & Would it incur any tax exportation? \\
\hline & & What is the common perception by developers and the public? \\
\hline & & Are there specific obstacles in the current rules/regulations? \\
\hline & Administration & Administrative cost: How hard is it to manage the process? \\
\hline & feasibility & Compliance cost: Is it hard for the public to comply with the policy? \\
\hline
\end{tabular}

Table 3 presents a framework to be used to assess each value capture policy. The four broad criteria that will be used to assess the policies are listed, along with any relevant sub-categorization of these criteria. In addition, the table lists some sample questions that might be asked to evaluate the proposed policies against these criteria. The criteria are not exhaustive, but follow closely sets of evaluation criteria identified by other reviews of the topic (Hayashi, 1989). They include:

- Economic efficiency, which relates to the ability of the policy to ensure an efficient allocation of society's resources. This definition is not necessarily limited to the efficiency as user charges, but may also refer to the ability to equate marginal benefits and costs of development.

- Equity, which describes the fairness of resource allocation according to different stratifications of society. Here we evaluate equity along two dimensions: benefit equity, which describes the 
distribution of benefits across different social strata; and ability-to-pay, which relates to how the burden of finance is distributed across various income groups under the different policies.

- Sustainability, which in this context will refer to the ability of the policy to serve as a reliable source of transportation revenue. It will be further divided according to the criteria of adequacy, growth potential, stability and, predictability.

- Feasibility, which will evaluate the policies according to their political and administrative feasibility.

Table 4 summarizes the qualitative evaluation of the policies with respect to the four key groups of criteria. Each of the criteria will be examined in turn, with reference to specific policies where necessary.

Table 4. Summary of evaluation of value capture policies

\begin{tabular}{|c|c|c|c|c|c|c|}
\hline & Efficiency & & & Sustainability & & asibility \\
\hline & $\begin{array}{l}\text { Price signals, } \\
\text { economic growth } \\
\text { promotion }\end{array}$ & $\begin{array}{l}\text { Costs and } \\
\text { Benefits to } \\
\text { payers }\end{array}$ & $\begin{array}{l}\text { Ability to } \\
\text { pay }\end{array}$ & $\begin{array}{l}\text { (adequacy, growth } \\
\text { potential, stability) }\end{array}$ & Political & Administrative \\
\hline $\begin{array}{l}\text { Land Value } \\
\text { Tax }\end{array}$ & Good & Good & $\begin{array}{l}\text { Slightly } \\
\text { regressive }\end{array}$ & $\begin{array}{l}\text { Broad base, modest } \\
\text { growth, fairly stable }\end{array}$ & Poor & Fairly simple \\
\hline $\begin{array}{l}\text { Tax Increment } \\
\text { Financing }\end{array}$ & $\begin{array}{l}\text { Little evidence on } \\
\text { applications in } \\
\text { transportation }\end{array}$ & Good & $\begin{array}{l}\text { Possibly } \\
\text { regressive }\end{array}$ & $\begin{array}{l}\text { Narrow, for limited } \\
\text { projects; keeps pace } \\
\text { with inflation, } \\
\text { incomes }\end{array}$ & Good & Complex, costly \\
\hline $\begin{array}{l}\text { Special } \\
\text { Assessments }\end{array}$ & Good & $\begin{array}{l}\text { Depends on } \\
\text { structure \& } \\
\text { exemptions }\end{array}$ & $\begin{array}{l}\text { Slightly } \\
\text { regressive }\end{array}$ & $\begin{array}{l}\text { Narrow base, } \\
\text { limited revenue, } \\
\text { one-time }\end{array}$ & Poor & $\begin{array}{l}\text { Difficult to } \\
\text { establish }\end{array}$ \\
\hline $\begin{array}{l}\text { Transportation } \\
\text { Utility Fee }\end{array}$ & Good potential & Good & $\begin{array}{l}\text { Slightly } \\
\text { regressive }\end{array}$ & $\begin{array}{l}\text { Stable, adequate, } \\
\text { predictable }\end{array}$ & Good & Simple \\
\hline $\begin{array}{l}\text { Negotiated } \\
\text { Exactions }\end{array}$ & Good & Good & $\begin{array}{l}\text { Neutral to } \\
\text { progressive }\end{array}$ & $\begin{array}{l}\text { Narrow, some } \\
\text { growth potential; } \\
\text { cyclical }\end{array}$ & Good & Simple \\
\hline $\begin{array}{l}\text { Development } \\
\text { Impact Fees }\end{array}$ & Good & Good & $\begin{array}{l}\text { Probably } \\
\text { neutral }\end{array}$ & $\begin{array}{l}\text { Narrow, adjustable } \\
\text { for growth; cy clical }\end{array}$ & Good & Low costs \\
\hline $\begin{array}{l}\text { Joint } \\
\text { Development }\end{array}$ & Good & Good & $\begin{array}{l}\text { Neutral or } \\
\text { slightly } \\
\text { progressive }\end{array}$ & $\begin{array}{l}\text { Narrow base, } \\
\text { limited revenue; } \\
\text { cyclical }\end{array}$ & Good & Complex \\
\hline Air Rights & Good & Good & $\begin{array}{l}\text { Neutral to } \\
\text { progressive }\end{array}$ & $\begin{array}{l}\text { Narrow base, } \\
\text { limited revenue; } \\
\text { cyclical }\end{array}$ & Good & Complex \\
\hline
\end{tabular}

\subsection{Efficiency}

The set of value capture policies considered here generally fares well in terms of economic efficiency criteria. Most of the policies provide important price signals, both to developers and to public infrastructure providers, about where to invest. As a provider of transportation services, government entities would be better able to prioritize investments under the criterion that those investments would create benefits greatly in excess of their costs, and that some or all of the benefit could be captured to finance the transportation investment. Policies in which developers are asked to contribute toward the provision of infrastructure (e.g. development impact fees, negotiated exactions, joint development, air 
rights) also promote more efficient development, as they more closely align incremental development costs with the beneficiaries of new development.

The efficiency impacts of two of the policies listed in Table 4 involve some uncertainty, and so their assessment is somewhat speculative. Transportation utility fees have the potential to enhance economic efficiency by more efficiently assigning road infrastructure costs among users and by providing more clear price signals to users regarding the costs of road provision. The extent to which transportation utility fees can serve this purpose depends largely on the basis of the fee. Some of the transportation utility fees adopted by local jurisdictions in the United States use relatively simple fees, such as flat, per-unit fees, while others distinguish between property types, square footage, or other variables that might correlate with trip generation. The latter type of fee would appear more favorable on efficiency grounds. Examining the efficiency implications of tax increment financing may also be difficult, as there are few examples of its use for transportation finance purposes relative to its more common use in promoting urban redevelopment.

\subsection{Equity}

The equity implications of value capture policies may be defined along two dimensions. The first relates to how closely the proposed policy adheres to the benefit principle of public finance; that is, how closely are the costs and benefits of a policy aligned across users. On this criterion, value capture policies generally perform quite well. One possible exception may be the use of special assessments, which often involve choices about the structure of the charge and whether to allow exemptions for certain groups of landowners. Assessments that take into account the location of properties relative to a transportation facility may promote benefit equity to a greater extent than those which simply charge all properties within a given threshold distance at the same rate. The use of exemptions or discounts for certain types of households (e.g., low-income, elderly) or classes of property is common in the adoption of special assessments. While such provisions may be used to promote fairness or to improve political feasibility, they may also weaken the relationship between the charges imposed to finance a transportation improvement and the benefits to landowners that result from that improvement.

The second dimension of the equity criterion relates to the distribution of costs among individuals on the basis of ability to pay. Thus, policies can be characterized as regressive (if they take a greater share of income from lower-income individuals), neutral, or progressive (if they take a greater share of income from higher-income individuals). The policies that target charges toward existing property owners (land value taxes, tax increment financing, special assessments, and transportation utility fees) tend to be slightly regressive, as they tend to function similarly to property taxes. Policies that involve imposing charges on new development (i.e., to developers or their customers/tenants) are more likely to be neutral to progressive, depending on the characteristics of end users and assumptions about patterns of incidence. Since most new housing development tends to be targeted toward middle to upper-income households, we assume that most infrastructure costs will ultimately be borne by these households under value capture methods of finance.

\subsection{Sustainability}

The sustainability of a revenue source, as defined here, relates to the adequacy, stability, and growth potential of a given revenue source. Some of the policies considered here involve jurisdiction-wide charges, such as land value taxes and transportation utility fees. These charges tend to be broad-based and have the potential to generate large amounts of revenue, possibly serving as a replacement for existing sources of revenue at the local level. They also tend to be fairly stable sources of revenue with modest rates of growth, as they apply to both existing and new development. 
The majority of the policies tend to involve a much narrower tax base and apply to some subset of properties within a jurisdiction. Some are limited in terms of geographic area, while others are limited to specific, new development projects. The result of this feature is that the amount of revenue these types of policies typically generate tends to be limited, and is more suitable for financing specific projects rather than serving as a replacement for existing, broad-based taxes such as property taxes. A narrow base may also reduce the stability of the revenue source, especially in cases where charges are imposed only on new development. The cyclical, boom-and-bust nature of real estate development makes these types of charges more volatile in terms of revenue potential.

\subsection{Feasibility}

The feasibility of the value capture policies can be assessed along two dimensions-political and administrative feasibility. Policies with a high degree of political feasibility tend to be those with a narrow base and that shift the burden of taxation away from existing homeowners in a particular jurisdiction. This explains the popularity of development impact fees, negotiated exactions, and other policies designed to make new development "pay its own way." Special assessments, despite having a narrow base, may have lower political feasibility due to their high visibility among existing property owners. The only other policy considered to have low political feasibility is the land value tax, as it bears many similarities to the highly visible and unpopular property tax.

In terms of administrative complexity, the policies are split roughly evenly among those that are fairly simple to implement and those that are more complex and costly to implement. Those that are easy to implement are generally able to take advantage of existing administrative structures. Local governments that have experience administering property assessment and taxation can adapt easily to administering a land value tax or transportation utility fee. Likewise, development impact fees and negotiated exactions should have a high degree of administrative feasibility, since they can be assessed within the development review process. The remaining four policies (special assessments, tax increment financing, joint development, and air rights) have certain features that make them administratively more complex, such as requirements for additional expertise in real estate management and law (joint development, air rights), legal restrictions on use (tax increment financing), and need for the development of legally defensible methods for setting charges (special assessments).

\section{Conclusion}

The identification of new sources of transportation revenue to replace motor fuel taxes will become a pressing issue, perhaps within the next decade, for units of government at all levels. State and local governments in particular may be well positioned to take advantage of value capture as a replacement source of revenue. As suggested by the general framework of transportation finance presented here, value capture policies may be part of a framework for setting charges that recognizes the different groups of beneficiaries affected by transportation investments. The framework suggests that a mix of general revenues, user fees, and land-based revenues may be appropriate, though the question of the optimal amount to be derived from each source remains open.

To the extent that value capture policies are adopted, policymakers must confront the tradeoffs implied by each policy. While many of the policies reviewed here may promote economic efficiency, they tend to have different profiles with respect to other important criteria, such as social equity, adequacy and stability, and feasibility. The choice of a particular policy may also hinge on whether the revenue source being sought is to be used to finance a specific project in a specific location, or whether it is designed to be the primary source of revenue for financing the transportation budget in an entire jurisdiction. The set 
of value capture policies presented here provide a great deal of choice and flexibility with which jurisdictions can adapt a particular policy to their own circumstances.

\section{Acknowledgements}

The article is based on a research project entitled Value Capture for Transportation Finance, which was funded by the Minnesota State Legislature, USA. Complete reports and additional documentation are available at http://www.cts.umn.edu/Research/Featured/ValueCapture/index.html.

\section{References}

Allen, W. B. (1987). Value capture in transit. Journal of the Transportation Research Forum, 28(1), 5057.

Batt, H. W. (2001). Value capture as a policy tool in transportation economics. American Journal of Economics and Sociology, 60(1), 195-228.

Dalvi, M., \& Patankar, P. (1999). Financing a metro rail through private sector initiative: The Mumbai Metro. Transport Reviews, 19(2), 141-156.

Debrezion, G., Pels, E., \& Rietveld, P. (2007). The impact of railway stations on residential and commercial property value: A meta-analysis. Journal of Real Estate Finance and Economics, 35, 161180.

Du, H., \& Mulley, C. (2007). The short-term land value impacts of urban rail transit: Quantitative evidence from Sunderland, UK. Land Use Policy, 24, 223-233.

Foldvary, F. E. (2005). Geo-Rent: A plea to public economists. Econ Journal Watch, 2(1), 106-132.

George, H. (1975). Progress and poverty. New York: Robert Schalkenbach Foundation.

Giuliano, G. (2004). Land use impacts of transportation investments: Highways and transit. In S. Hanson, \& G. Giuliano (Eds.), The geography of urban transportation (3rd ed., pp. 237273). New York: Guilford Press.

Harsman, B., \& Quigley, J.M. (2010). Political and public acceptability of congestion pricing: Ideology and self-interest. Journal of Policy Analysis and Management, 29(4), 854-874.

Hayashi, Y. (1989). Issues in financing urban rail transit projects and value captures. Transportation Research Part A, 23(1), 35-44.

Huang, H. (1996). The land use impacts of urban rail transit systems. Journal of Planning Literature, $11(1), 17-30$.

Ryan, S. (1999). Property values and transportation facilities: Finding the transportation land-use connection. Journal of Planning Literature, 13(4), 412-427.

Smith, J. J., \& Gihring, T.A. (2006). Financing transit systems through value capture: An annotated bibliography. American Journal of Economics and Sociology, 65(3), 751-786.

Stopher, P. R. (1993). Financing urban rail projects: The case of Los Angeles. Transportation, 20(3), 229-250.

Vadali, S. R., Aldrete, R.M., \& Bujanda, A. (2009, January). A financial model to assess value

capture potential of a roadway project. Paper presented at the 88th Annual Meeting of the Transportation Research Board, Washington, D.C.

Vickrey, W. (2001). Site value taxes and the optimal pricing of public services. American Journal of Economics and Sociology, 60(5), 85-96. 